\title{
Preparation of International Business Contracts in Facing the ASEAN Economic Community Era
}

\author{
Sahlan \\ Faculty of Law Tadulako University \\ Jl. Soekarno-Hatta KM. 9, Palu, Central Sulawesi 94117, Indonesia. \\ Tel./Fax:+62-451-422611 E-mail: sahlanilyas@gmail.com \\ Submitted: May 27, 2016; Reviewed: Sep 14, 2016; Accepted: Oct 3, 2016
}

\begin{abstract}
This article reviews the preparation for composing and formulating the international business contracts in facing the ASEAN Economic Community era. The study used the normative approach by collecting the materials related to the international business contracts. The outcomes of the research indicate that constitutionally, the Indonesian government must provide protection and equitable legal certainty for Indonesian citizens who intend to conduct business transactions within the framework of AEC. Format and writing techniques of international business contracts is compulsory known by the business people and their legal consultants that they do not suffer losses due to errors in the preparing of contract that violates the rules and provisions of international business contract.
\end{abstract}

Keywords: ASEAN; ASEAN Economic Community; International Business Contract

DOI: 10.20956/halrev.v2i3.702

\section{INTRODUCTION}

ASEAN's vision as a joint economic area has been announced since the meeting in Kuala Lumpur in December 1997 marked the beginning of the history of economic integration in this region. Meanwhile, the inauguration of the ASEAN Economic Community or abbreviated as AEC had just happened at the summit, it known as Concord II in Bali in October 2003. The purpose of the inauguration of the ASEAN Economic Community is to do integration of this region in 2020. ${ }^{1}$ Thus, ASEAN

\footnotetext{
Masnur Tiurmaida Malau. (2014). “Aspek Hukum Peraturan dan Kebijakan Pemerintah Indonesia Meng-
}

countries will undergo a phase change in the economy by having a single market and production base called the ASEAN Economic Community (AEC). AEC is a form of economic integration among ASEAN countries in order to obtain the ASEAN economies stable, profitable and highly competitive. In short, the AEC is free trade areas in Southeast Asia are based on 4 (four) pillars: 1) a single market and production base, 2) a region with high competitiveness in the economy, 3) equitable economic

hadapi Liberalisasi Ekonomi Regional: Masyarakat Ekonomi ASEAN 2015." Jurnal RechtsVinding, 3(2): 163-182. 
development, and 4) full integration into the economy globally. In addition, there will be the elimination of tariffs to get the flow of goods/services/investments/capital freely among the countries in the ASEAN region. ${ }^{2}$

Integration of ASEAN economic region above would lead to some legal consequence and also business as an actor or business people coming from different countries, which certainly has some differences. In connection with the preparation of international business contracts, the parties to a transaction or business activity would be entering into business contracts that are considering the parties. Needed a legal framework at ASEAN level so that the parties to a business obtain legal certainty.

ASEAN Economic Community requires a legal order that is able to provide legal certainty for the parties and at the same time it not conflict with the rules of commercial law and international business which has been ratified by many countries. International commercial contract that reflects the results of harmonization and legal unification of various different legal systems indicates the presence of awareness and willing the international communities to institutionalize provisions are more uniform governing all aspects related to the international commercial transactions as outlined in a contract. Principles, terminology and provisions developed have been formulated in such a way so as to be the playing rule clearly to the parties in various international commercial

Ryan Faza Prasetyo and I Putu Artama Wiguna. "Menilai Kesadaran dan Kesiapan Kontraktor di Indonesia Menghadapi Masyarakat Ekonomi ASEAN.” (Proceeding) Seminar Nasional Manajemen Teknologi XXII, Prodi MMT - ITS, Surabaya, 24 January 2015, pages. $1-2$ transactions are made and implemented between the parties. ${ }^{3}$

In general, according to the results of international commercial contract study in the context of its development in Indonesia, things that need to be considered from the development of international commercial contract among others international commercial contract, international sales contracts, construction contracts, infrastructure contract and electronic contracts. Meanwhile, in particular, there are several specific issues of the development of international commercial contract that need to be considered in an effort suitability and/or improvement of Indonesian national contract law.

The special issues, includes the principles of international contract law, contract establishment, contract content, contract enforcement, contract interpretation, applicable law and choice of contracts, as well as the settlement of contractual disputes. If it is associated with the prospects of development of international commercial contracts, there are several issues that need serious attention, namely national arrangements related to international commercial contract, Indonesia's participation in the discussion of international commercial contract development, the need for improvement of the rules of contract law related to international commercial contract, as well as a variety of steps that need to be reached. ${ }^{4}$

There are indications that there are still little legal experts in Indonesia which master the legal theory and technique of interna-

\footnotetext{
Ida Bagus Rahmadi Supancana. (2012). Perkembangan Hukum Kontrak Dagang Internasional. Jakarta: Badan Pembinaan Hukum Nasional, p. 39

$4 \quad$ Ibid. p. 53
} 
tional business contracts drafting. Therefore, it is often found business people or lawyers in Indonesia that drafting the international business contracts are not in accordance with the theory of international law or the international customs practices.

Occasionally, business people in Indonesia are simply handed to the counterpart so that foreign parties are dominant in determining the content and format of the international business contracts. ${ }^{5}$ Thus, there is a potential problem due to the drafting of international business contracts that are not in accordance with the rules of private international law and its content even more by foreign parties or counterparties. If legal issues or disputes arise between the parties, then when do settlement in a foreign court or international arbitration institution, often the Indonesia often defeated because of international business contracts are made to violate the rules of international private law and its contents are determined more by foreign parties. ${ }^{6}$

Facing the era of ASEAN Economic Community, business people in the region of ASEAN must have a clear legal framework to protect the parties in the transaction of business as outlined in the international business contract agreement. The Indonesian side is required to play an active role in preparing the legal framework, particularly related to international business contract law. This paper aims to prepare the international business contracts for business people and legal counsel that accompanied it.

\footnotetext{
Afifah Kusumadara. (2013). Kontrak Bisnis Internasional. Jakarta: Sinar Grafika, pages. 1-2
}

\section{ANALYSIS AND DISCUSSION}

Scope of Contract and International Contracts

Definition and legal terms in Indonesia is many derived from the Dutch term as main law source in Indonesia. Similarly, the term of contracts in Indonesia, this also comes from the Dutch term as the original source, verbintenis and overeenkomst. ${ }^{7}$ It is up to now still a debate as each expert Indonesia's civil law has its own arguments and different skills.

There is some definition of contract as proposed by experts, ${ }^{8}$ namely: According to Lawrence M. Friedman, a contract is a set of laws that only regulate certain aspects of the market and regulate certain types of agreement; According to Michael D. Bayles, a contract is a rule of law relating to the implementation of agreement or consent; According to Van Dunne, a contract is a legal relationship between 2 (two) or more based on the agreed word to raises a law; and according to Article 1313 Civil Code of Indonesia, a contract is an act by which one person or more bind himself against one or more other. According to Black's Law dictionary, ${ }^{9}$ contract is defined as:

"An agreement between two or more persons which creates an obligation to do or not to do a peculiar thing. Its essentials are competent parties, subject matter, a legal consideration, mutuality of agreement, and mutuality of obligation."

Arfiana Novera and Meria Utama. (2014). Dasar-dasar Hukum Kontrak dan Arbitrase. Malang: Tunggal Mandiri, p. 5

H. Priyatna Abdurrasyid. (2002). Arbitrase dan Alternatif Penyelesaian sengketa (Suatu Pengantar). Jakarta: Fikahati Aneska, p. 56

$9 \quad$ Bryan A. Garner. (1999). Black's Law Dictionary. $7^{\text {th }}$ edition. St. Paul Minn: West Group, p. 268 
Another definition as cited in Charles and Nathan ${ }^{10}$ which stated that: "Contract is an agreement between two or more persons not merely a share belief, but common understanding as to something that is to be done in the future by one or both of them." Contract law is already known from Hammurabihingga code in Roman law, the legal system in countries that applied the Continental European legal traditions, including Netherlands and also Indonesia, have source from Roman law, including the Civil Code in it there are many articles regulating contract.

In international realm, there is no law like the Civil Code regulating agreement or contract, but there are conventions such as Wina Convention 1969, DenHaag Convention, and others. In Indonesia, contract develop both in custom law, land law, family and marriage, about grants, escrow, debts, lending, exchange, purchase, or a guarantee of a moving thing.

In contrast to the international contracts is dynamic, its development cannot be separated from the development of mankind with his/her trade activity in outline marked with four forms of development contracts, as follows: ${ }^{11}$

1) International Contract Law in Lex Mercatoria

Lex Mercatoria or traders legal are rules of law made by the traders and for traders. Judicial body grows because the need of traders to pour their agreement/contract has been reached between them.

10 Charles L. Knapp and Nathan M. Crystal. (1993). Problems in Contract Law Cases and Materials. UK: Little Brown and Company, p. 2

11 Arfiana Novera and Meria Utama. Op. Cit., Pages. 6-8
2) International Contract Law in National Law

With the rules made by the traders for their interests, the government that feels to regulate it in the $19^{\text {th }}$ century countries began to draft contracts law in its national legal system and enacted in a Code of Law. In Indonesia, as known it contained in the Second Book of BW adopted from the Netherlands.

3) International Contract Law in Standard Contract

After the end of World War II, traders have trading business that establishes trader organization. The aim of this trade organization is to facilitate their trading activities, by introducing a form of standard contract. In the development of standard contract got pros and cons of its use, in a side it looked deviate from the principle of freedom of contract because generally it have been made unilaterally by one party first. And otherwise, contract is useful for shortening time that needed to formalities closure of negotiating trade transactions.

4) International Contract Law and International Treaties

At this stage, emerges international treaties that established by the state or institutions, includes contains rules of harmonization of national contract law. And also, regulates the international habit, which is known as NewLex Mercatoria.

5) Contract Law in the Virtual World Globalization in the trade field is supported by the development of tech- 
nology to encourage the creation of a new trading system in terms of trade, using the internet as a means of connecting trade, using internet as a connection that cannot be conducted conventionally again. Transactions, contract agreement, including dispute settlement can be done through information technology, namely the Internet. For that, established institutions that regulate transaction issues through information technology, such as UNCITRAL (United Nation Commission on International Trade Law) which succeed formulate a formulation of law, namely UNCITRAL Model Law on Electronic Commerce in 1996 dan United Nations Convention on the Use of Electric Communications in International Contract.

Trade activities and international business transactions conducted by parties according to the agreements stipulated in an international contract. International contracts has a very important position as a major reference to the parties in the implementation of the agreed terms, even to the determination of how settlement will be reached if the future performance of the contract cannot be realized as it should be.

Sudargo Gautama ${ }^{12}$ defines international contract as national contracts which are foreign element. Theoretically, foreign elements in a national contract, as follows:

1) Different nationality;

2) The Parties have a legal domicile in a different country;

12 Sudargo Gautama. (1976). Kontrak Dagang Internasional. Bandung: Alumni, p. 7
3) The law chosen is foreign law, including the rules or principles of international contract to the contract;

4) Implementation contracts abroad;

5) Dispute settlement carried out abroad;

6) The contract was signed abroad;

7) Object contracts abroad;

8) The language used in the contract is a foreign language; and

9) The use of foreign currency in the contract. ${ }^{13}$

Generally, in the international law contract, there are two fundamental principles includes: 1) sovereignty principle/rule of national law; and 2) freedom of the contract or the party's autonomy. This reflects that national law plays a very important in the establishment of international contract and the inviolability of its existence. The binding force of national law is absolute and legal position is as the most preferred. Every subject, object, action, event, and cause of law including commercial transactions that stipulated in a contract that occurred in the territory of a country is subject absolutely to the national law. ${ }^{14}$

In fact, the national law in each country relating to contract law is very varied due to the different legal systems in each of these countries. Even if there are similarities, only associated with the general principles are not easy to apply as a guide in the formation of international contracts that the scope of object is so wide, whereas the rules that are substantively different in each country. These conditions are certainly not conducive to the activity of the international business

\footnotetext{
13 Huala Adolf. (2008). Dasar-dasar Hukum Kontrak Internasional. Bandung: Refika Aditama, p. 4

14 Ibid., pages. 19-20
} 
world. The big difference in the rules in each country will inhibit the implementation of international business transactions that require speed and certainty. ${ }^{15}$

Problems often encountered in international business contract law is to ensure the rights and obligations of the parties to commercial law contrast/ international business because they are in different countries and of course bound by different legal rules. This problem becomes more serious if it is found the applicable law in a country is a legal product that is out of date or do not accommodate the changes.

Such conditions also occurred in Indonesia, where the general rules of contract/ agreement still based on colonial legal product already out of date. In relation to the international law contract, the provisions of Civil Code especially the Third Book of the Engagement and more specifically set forth in Chapter II of the Engagement born of the Treaty did not fully accommodate the principles of international contracts, so it still has problems related to contracts in trading activities and international business transactions. The arrangements of contract/ agreements in Civil Code are increasingly marginalized as more complex and complicated contracts formed mainly of cross country. The legal provisions of engagement in Civil Code are partially out of date as globalization that emphasizes the rule known as the convention law, community law, and the model law.

In this case, the harmonization of laws is a demand and the needs that must be met for the parties in the implementation of trade

15 Sudargo Gautama, Op. Cit., p. 29 or international business transactions. According to Hannu Honka, efforts to harmonize can be done in several ways, namely:

1) Regulation of national legislation in the field of contract;

2) The use of standard contracts;

3) The application of international customs law;

4) The international legal principles;

5) Decision of arbitration court; and

6) Harmonization as the legal guide/ guidelines and legal doctrine. ${ }^{16}$ In addition, in detailed, Roy Goode stated that the harmonization of the laws can be done through:

1) A multilateral convention without a uniform law as such;

2) A multilateral convention embodying a uniform law;

3) A set of bilateral treaties;

4) Community legislation, typically, a directive;

5) A model law;

6) A codification of custom and usage promulgated by an international nongovernmental organization;

7) International trade terms promulgated by such an organization;

8) Model contracts and general contractual conditions; and

9) Restatement by scholars and experts. ${ }^{17}$ Harmonization of contract law in an international context is effectively carried out by institutions or international organizations, both of which are public such as the United Nations (UN) with the body of apparatus $\overline{16}$ Huala Adolf, Op. Cit., p. 31

17 Setiawan. (1994). Naskah Akademik Peraturan Perundang-Undangan Perikatan, Pengganti Burgerlijk Wetboek/Std. 1847-23. Buku Ketiga, Titel 1-4. Jakarta: BPHN, p. 79 
such as the United Nations Commission on International Trade Law (UNCITRAL) or independent international organization such as the International Institute for the Unification of Private Law or the Institute International Pour L'unification Du DroitPrive commonly known as UNIDROIT. UNCITRAL is a body of apparatus of UN was established in 1966 by the UN's General Assembly (Resolution 2205 (XXI) of December 17, 1966). Consideration of the establishment of UNCITRAL is to reduce or overcome obstacles in international trade caused by differing arrangements of each country in the field of international trade. ${ }^{18}$ UNIDROIT is an independent international organization based in Rome, Italy in which the purpose of establishment is to study needs and methods for modernization and harmonization of international trade law between state and union countries in the world. ${ }^{19}$

In principle, the establishment of UNIDROIT has similar background with UNCITRAL, namely in order to overcome obstacles in the implementation of international trade which are caused by differences in national laws of each country. The role carried out by various international organizations is issued various treaties or international agreements that can be used as guidelines in the preparation of international contract. In this case, UNCITRAL has issued 1980 United Nations Convention on Contracts for the International Sale of Goods (CISG) and UNIDROIT has issued UNIDROIT Princi-

18 Origin, Mandate and Composition of UNCITRAL. Available online at: http://www.incitral.org/en/about/ origin.html. Accessed on Jun 13, 2014.

19 UNIDROIT: An Overview. Available online at: http:// unidroit.org/dynasite.cfm?dsmid=84219. Accessed on Jun 13, 2014. ples of International Commercial contracts (UPICCs) in 1994 and then revised in 2004. The international treaty in contracts, as well as national law, is the main source of law (primary). This source is not less important than the other main sources of law, namely the national legal and contract documents that govern the parties. ${ }^{20}$

\section{Legal Sources of International Business Contracts}

Before discussing the legal sources of international business contract, firstly, author look at the authority of international trade principles. In the renewal of commercial law in Indonesia, the living law aspect is very concerned which includes the atmosphere of mysticism and philosophy of the nation Indonesia originating from the "Pancasila" and the Preamble of the 1945 Constitution. Article $28 \mathrm{~A}$ of the 1945 Constitution is a fundamental right for every person to carry out its business activities in the trade to sustain life and livelihood, juncto Article 28D (1) which states that every person entitled to recognition, security, protection, and legal certainty and equal treatment before the law. Two clauses in the 1945 Constitution is enough to guarantee protection and certainty for the parties in the course of trade in Indonesia, where the government is obliged to protect, recognize its trading business activities. ${ }^{21}$

In the basis of fundamental legal above, the government is obliged to provide security, protection and legal certainty for all citizens who will do business internationally.

$20 \quad$ Huala Adolf, $O p$. Cit., p. 76-77

21 Agus Budianto. "Pembaharuan Kitab Hukum Dagang Indonesia: Antara Kodifikasi, Kompilasi dan Konsolidasi." Asy-Syir'ah Jurnal Ilmu Syari'ah dan Hukum, Vol. 47, No. 2, December 2013, page. 708 
Spirit to reform its trade system in Indonesia is already demands cannot be ignored anymore, considering the development of legal science and the trading behavior is very advanced, especially in the face of economic integration in the ASEAN Economic Community. International trade principle recognize that a "fundamental freedom", where anyone should be liberated to trade, which should not be limited by differences in religion, race, creed, politics, the legal system, and others. ${ }^{22}$ This was confirmed by Article 4 of the Charter of Economic Rights and Duties of States also recognizes that every state has the right to engage in international trade. ${ }^{23}$

In the international trading system, grouping source of law is followed and has authority for its members as a source of law, can be divided into hard law and soft law. ${ }^{24}$ Sources of law with hard law, includes:

1) UN Convention on International Sales of Goods 1980.

2) Convention on the Law Applicable to Contracts of International Sales of Goods 1986.

3) Convention on the Law Applicable to Agency 1978.

4) International Convention on Travel Contract 1970.

5) Convention Relating to a Uniform Law on the International Sales of Goods 1964.

6) Convention on the Law Applicable to International Sales of Goods 1955.

22 Huala Adolf. Hukum Ekonomi Internasional: Suatu Pengantar. Cet. Ke-3 (Jakarta: Rajawali Press, 2012), Page. 17

23 Agus Budianto, Op. Cit., p. 709

24 Ida Bagus Rahmadi Supancana, op. cit., Pages. 10-30
7) Convention for the Unification of Certain Rules for International Carriage by Air, Montreal, 1999.

8) UN Convention on the Use of E-Communication in International Contract 2005.

9) Convention on International Interest in Mobile Equipment 2001.

10) UN Convention on the Carriage of Goods by Sea (The Hamburg Rules) 1978.

11) UN Convention on Contracts for the International Carriage of Goods Wholly or Partly by Sea (the Roterdam Rules) 2008.

Meanwhile, there are general principles that apply in the world of international trade, as soft law, includes:

1) UNIDROIT Principles of International Commercial Contract 2010. UNIDROIT Principles of International Contract is the result of harmonization in the field of Contract Law of various different legal system, both Civil Law; Common Law; Socialist Legality; Shariah; and Canonic Law. This was done to facilitate international trade activities.

2) Uniform Rules on Contract Clauses for an Agreed Sum upon Failure of Performance 1983;

3) Uniform Rules Concerning the Contract of International Carriage of Goods by Rail (CIM), 1999;

4) UNCITRAL Legal Guide on Drawing Up International Contracts for the Construction of Industrial Works;

5) Promoting Confidence in E-Commerce: Legal Issues on International 
Use of Electronic Authentication and Signature Method 2007;

6) UNCITRAL Model Law on Electronic Signature with Guide to Enactment 2001;

7) UNCITRAL Model Law on E-Commerce of 1996 with Guide to Enactment, with additional Article 5 bis as Adopted in 1998;

8) UCP 600 (Uniform Customs and Practice for Documentary Credit). UCP is a major source of reference for all the countries in the world in the implementation of trade transactions, particularly in the use of letters of credit (L/C).

9) Incoterms 2010 Incoterms has been widely used since 1936 in a variety of international trade transactions. Incoterms are international commercial terms used in the business world to clarify the implementation of the obligations of each party to a contract.

10) ICC Model Contracts and Clauses;

11) ICC E-Terms 2004;

12) ICC Guide to E-Contracting.

Moreover, in international trade known fundamental principles by Aleksancer Goldstajn, namely: The principle of parties' freedom to the contract; the principle of pacta sunt servanda; the principle of the use of arbitration; and the fundamental principle of communications freedom (navigation). ${ }^{25}$ The principle of international trade is in line with the principles of the relationship of the parties set out in the Civil Code of Engagement. The principle of freedom to a contract is a universal principle in the law of freedom

$25 \quad$ Huala Adolf. (2008). Op.Cit., p. 17 of trade is, of course, must not be contrary to law, public interest, morality, decency and others. $^{26}$

In addition to the principle of trade, the spirit of commercial law reform in Indonesia is also influenced by Good Corporate Governance (GCG). The practice of good corporate governance, its beginning as requirements of the creditors, including the International Monetary Fund (IMF), World Bank and Asean Development Bank (ADB) as part of the international assistance to restore the economy of Indonesia. These requirements are then formulated in the Indonesian corporate governance code of conduct as guidelines of business world in the implementation of good corporate governance principles. $^{27}$

The practice of good corporate governance, implemented with the following principles: ${ }^{28}$

1) Transparency, openness in carrying out a process and in disclosing materials and relevant information about the corporation;

2) Independence, a state where Limited Company is free from the influence/ pressure other parties that are not in accordance with the corporation; and

3) Accountability, a system of accountability in the implementation of duties and authority of the Limited Company.

26 Agus Budianto. (2013). Op.Cit., p. 714

27 I Ketut Mardjana. (2000). "Corporate Governance dan Privatisasi." Jurnal Reformasi Ekonomi, Vol. 1, No. 2, October-December 2000, Page. 29

28 Decision of the Minister of Investment and Development of State-Owned Enterprises No. Kep-23/M-PM. PBUMN/2000 dated 31 May 2000 on The Development of Good Corporate Governance in Limited Company. 
Format of International Business Contract and Technique of Contract Content Writing

The outline of international business contracts are generally, includes: ${ }^{29}$

a) Title;

b) Introductory paragraph;

c) Preambles;

d) Definitions;

e) Consideration;

f) Conditions precedent;

g) Representations and warranties;

h) Covenants;

i) Indemnities or guaranties or releases;

j) Events of defaults;

k) Remedies;

1) Boilerplate;

m) Signature block;

n) Exhibits or schedules;

Furthermore, it explain that the technique of contract writing can be carried out according to common techniques that have become standard in the drafting of international business contracts today, starting from the introductory to the concluding (exhibits). ${ }^{30}$

\section{Part of contract introductory}

Part of contract introductory consists of titles, introductory paragraph and recitals. The title is written on the top line on the first page of the contract by using capital letters, always written on the first line, in a central position, and underlined or bolded. Furthermore, the title should mention the type of contract by using general terms, such as "Sales Agreement" or "Joint Venture Agreement". Other things such as the date of contract and the

29 Afifah Kusumadara. Op.Cit., p. 21-23

$30 \quad$ Ibid., p. 25-37 parties are written separately under the title. Here is an example of a title or a title written on the cover page of a contract:

\section{PURCHASE AND SALE AGREEMENT}

Dated January 31, 2014

between

PT. XYZ

as a Seller and

PT. ABC

as Buyer

After the title, followed by the introductory paragraph, which contains the following elements: the type of contract; date of contracts; real identity of the parties (name and domicile of the law); designation for the parties (defined terms).

Types of contracts are written in the introductory paragraph is the same as the title of the contract, such as Credit Agreement, Sales Agreement, and so forth. Meanwhile, the date of contract is not necessarily the effective date of the contract or binding upon the parties. The date that is written in the introductory paragraph could be the date of signing the contract by the parties, or the date when the contract is drawn up, prepared, or just a specific date for administrative purposes.

If the parties to the contract intend to make date in the introductory paragraph as the effective date of the contract, the date of the introductory paragraphs should explicitly (explicit and clear) referred to as the "effective date". If parties to the contract do not intend to make a date in introductory paragraphs as the effective date of the contract, the date of the introductory paragraphs need not given with the word "effective date". Effective Date may also be written in the con- 
cluding part of the contract.

Here is an example of an introductory paragraph in a Purchase and Sale Agreement in which the date on it is not intended to be the Effective Date of contract:

This Purchase and Sale Agreement (the "Agreement") dated as of December 1, 2014, is between PT. ABC ("Seller"), a corporation duly organized and existing under the laws of Indonesia, dan Cosmos International, Ltd. ("Buyer"), a corporation duly organized and existing under the law of Japan.

In the practice of drafting international business contracts, often used the word "as $o f$ " of the date of contract for reasons of practicality without compromising the legal certainty of the contract. Then, recitals paragraph or preambles are written directly below the introductory paragraph. Recitals aims to explain the facts associated with the contract, for example, aims and objectives of the parties, the nature of the contract, the background of the contract, etc. Here is a sample recitals paragraph in a Loan Agreement:

Whereas,

A. The Borrower proposes to borrow from the Bank, and the Bank proposes to lend to the Borrower, an aggregate amount of $\$ 100,000$ (one hundred thousand dollars).

B. The Borrower intends to use the loan to improve its waste disposal system.

C.

The word "Whereas" is commonly used by lawyers in recitals drafting of international contracts. Recitals should be written in Plain English and only write about the facts and purpose of the parties, not promises and obligations of the parties. Therefore, it is not appropriate to use words that can be interpreted as an agreement binding the parties, for example, agree, shall, must, etc. in recitals paragraph.

Recitals are the very end at the preamble of the contract before the Body of Contract. Therefore, need a transition sentence that connects the preamble part of the contract with the body of contract.

\section{Body of Contract}

Body of contract governing the rights and obligations of the parties, promises, to legal effort that can be done by the parties in the event of default under the contract. The body of contracts is generally written in article format, followed by verses, as well as by sub-headings and numbering for each article. Generally, the body of international business contracts generally includes:

a) Definition;

b) Consideration;

c) Conditions precedent;

d) Representations and warranties;

e) Covenant;

f) Indemnities or guaranties or releases;

g) Events of defaults;

h) Termination of contract;

i) Remedies; and

j) "Boilerplate"

\section{Article (section) definitions}

The definitions are generally placed on the first chapter in international business contracts. Article definition is very helpful for international contracts that parties coming from two or more different countries that have different legal systems. It is intended to give a definite meaning to the parties on words or symbols used. For example, the 
word "Dollars" or " $\$$ " can be interpreted differently, could mean the US dollar, Australian dollar, Canadian dollar, Hongkong dollar, and so on.

Contract terms to be defined in article definition should be written in alphabetical order and the terms are written between double quotes, with the prefix capital letters and italics or bold type, followed by the definition or meaning.

\section{Considerations}

Article Consideration is the soul of an international business contracts. In Article Consideration parties to the contract are required to give to the parties each other, once entitled to receive something (money, services, goods, etc.) as payoff. Here is a sample Article Consideration of a contract Loan Agreement:

\section{Section 2}

COMMITMENT

The Bank agrees to lend the Borrower, an aggregate amount of $\$ 100,000$ (one hundred thousand dollars).

Section 3

INTEREST

Interest of the loan shall be

\section{Section 4}

REPAYMENT

The Borrower shall repay the Loan and the Interest under the terms in Schedule 1.

\section{Conditions precedent}

Generally, conditions precedents are written after article of consideration. In article conditions precedent is regulated that the obligations of the parties to the contract can only be enforced if certain terms and conditions that have been agreed by the parties have been met. Here is an example of clause Conditions Precedent in a Loan Agreement:
Article 5

\section{CONDITIONS PRECEDENT}

The obligation of the Bank to give the Loan to the Borrower is subject to the condition that the Bank receives no later than 31 December 2013 three executed copies of each of the documents listed below:

(a) A Promissory Note duly executed and delivered by the Borrower.

(b) An Opinion of Counsel to the Borrower.

(c) Schedule of Liens and Other Encumbrances on Property of the Borrowers.

(d)

\section{Representations and Warranties}

Representations and warranties are often written in a subtitled "Representations and Warranties." The meaning of Representations is statements about facts that exist or "present" (happening). While the meaning of Warranties is similar to the Representations, only statements in the Warranties are also intended to suggest that the facts that are happening (present) will continue in the future (in the future).

In general, a written statement in Article Representations and Warranties contain statements about the accuracy of financial statements, the sale value of the company, the absence of claims from third parties on the object of the agreement, the contract will not violate the applicable national law, etc.

\section{Covenant}

Literally, Covenant means a promise to do something (positive covenant) and promise not to do anything (negative covenants). Here is an example of Article Covenant:

\section{Section 7 \\ COVENANTS}

(a) The Borrower shall enable representatives of the Bank to examine its properties and records at any reasonable times.

(b) The Borrower shall promptly give notice to the Bank of each Default or Event of 
Default that has or might have a materially adverse effect on its ability to perform its obligations under this Agreement or the Promissory Note.

\section{Indemnity}

Indemnity in the context of the international business contract can be interpreted as a treaty clause in a business contract made by one party to the contract to protect and bear and free other party from any loss, expense, liability, and third party claim arising from the implementation of their business contract. Here is an example of Article Indemnity in a Sales Agreement:

\section{Article 8 \\ INDEMNITY}

The Seller shall hold harmless and indemnify the Buyer any losses, liabilities, and claims arising out of or relating to this transaction.

\section{Guaranty}

Article Guaranty is a section of treaty made by Guarantor which ensures that the Guarantor would meet its contractual obligations of either party to the contract, in terms of the guaranteed party fails to meet its contractual obligations.

\section{Events of default and remedies}

Article Event of Default set up an incident where one party to a business contract cannot implement the contents of contract. After the parties agreed the events what they categorize as events of default on their contracts, then they also have to make a deal what legal remedies which may be taken by either party of their respective events of default.

\section{Boilerplate}

Boilerplate set up technical element such choice of law of the parties, the choice of institution to dispute settlement, the official language of the contract, force majeure, notice, duration or terms of agreement, severability, integration, amendment, anti-waiver, counterpart, and assignment (transfer of contract).

\section{Back of the contract}

Generally, the concluding part of international business contracts consist of: 1) concluding clause; 2) signature block; 3) exhibits.

\section{CONCLUSION}

The economic integrity of the Southeast Asian region are contained in the ASEAN Economic Community. Various parties will be involved in business activities must prepare for the liberalization of trade between countries in the region. Constitutionally, the Indonesian government must provide protection and equitable legal certainty for Indonesian citizens who intend to conduct business transactions within the framework of AEC.

The parties who intend to conduct business transactions and legal consultants also advised to study the general business contracts and international business contracts ranging from definitions, sources of law that are hard law or soft law to provide legal insight to be able entered into a contract without violating the clauses and provisions of international law and business regulations that are under the international law. Format and writing techniques of international business contracts is compulsory known by the business people and their legal consultants that they do not suffer losses due to errors in the preparing of contract that violates the rules and provisions of international business contract. 


\section{BIBLIOGRAPHY}

Afifah Kusumadara. (2013). Kontrak Bisnis Internasional. Jakarta: Sinar Grafika.

Agus Budianto. (2013). "Pembaharuan Kitab Hukum Dagang Indonesia: Antara Kodifikasi, Kompilasi dan Konsolidasi." Asy-Syir'ah Jurnal Ilmu Syari'ah dan Hukum, Vol. 47, No. 2, December 2013.

Arfiana Novera and Meria Utama. (2014). Dasar-dasar Hukum Kontrak dan Arbitrase. Malang: Tunggal Mandiri.

Bryan A. Garner. (1999). Black's Law Dictionary. $7^{\text {th }}$ edition. St. Paul Minn: West Group.

Charles L. Knapp and Nathan M. Crystal. (1993). Problems in Contract Law Cases and Materials. UK: Little Brown and Company.

H. Priyatna Abdurrasyid. (2002). Arbitrase dan Alternatif Penyelesaian sengketa (Suatu Pengantar). Jakarta: Fikahati Aneska.

Huala Adolf. (2008). Dasar-dasar Hukum Kontrak Internasional. Bandung: Refika Aditama.

Huala Adolf. (2012). Hukum Ekonomi Internasional: Suatu Pengantar. Cet. Ketiga. Jakarta: Rajawali Press.

I Ketut Mardjana. (2000). "Corporate Governance dan Privatisasi." Jurnal Reformasi Ekonomi, Vol. 1, No. 2, OctoberDecember 2000.
Ida Bagus Rahmadi Supancana. (2012). Perkembangan Hukum Kontrak Dagang Internasional. Jakarta: Badan Pembinaan Hukum Nasional.

Masnur Tiurmaida Malau. (2014). "Aspek Hukum Peraturan dan Kebijakan Pemerintah Indonesia Menghadapi Liberalisasi Ekonomi Regional: Masyarakat Ekonomi ASEAN 2015." Jurnal RechtsVinding, 3(2): 163-182.

Origin, Mandate and Composition of UNCITRAL. Available online at: http:// www.incitral.org/en/about/origin. html. Accessed on Jun 13, 2014.

Ryan Faza Prasetyo and I Putu Artama Wiguna. "Menilai Kesadaran dan Kesiapan Kontraktor di Indonesia Menghadapi Masyarakat Ekonomi ASEAN." (Proceeding) Seminar Nasional Manajemen Teknologi XXII, Prodi MMT ITS, Surabaya, 24 January 2015.

Setiawan. (1994). Naskah Akademik Peraturan Perundang-Undangan Perikatan, Pengganti Burgerlijk Wetboek/ Std. 1847-23. Buku Ketiga, Titel 1-4. Jakarta: BPHN.

Sudargo Gautama. (1976). Kontrak Dagang Internasional. Bandung: Alumni.

UNIDROIT: An Overview. Available online at: http://unidroit.org/dynasite. $\underline{\mathrm{cfm} ? \mathrm{dsmid}=84219}$. Accessed on Jun 13, 2014. 